\title{
The Role of Networking Capability on Organization Performance: A Perspective of Private Universities in Kenya
}

\author{
Ruth Ndanu King’oo ", Linda Kimencu, Godfrey Kinyua \\ School of Business, Kenyatta University, Nairobi, Kenya \\ Email address: \\ kingoondanu@yahoo.com (R. N. King'oo), kimencu.linda@ku.ac.ke (L. Kimencu), kinyua.godfrey@ku.ac.ke (G. Kinyua) \\ ${ }^{*}$ Corresponding author
}

To cite this article:

Ruth Ndanu King'oo, Linda Kimencu, Godfrey Kinyua. The Role of Networking Capability on Organization Performance: A Perspective of Private Universities in Kenya. Journal of Business and Economic Development. Vol. 5, No. 3, 2020, pp. 178-186.

doi: $10.11648 /$ j.jbed.20200503.18

Received: August 17, 2020; Accepted: August 31, 2020; Published: September 10, 2020

\begin{abstract}
Private Universities in Kenya have continuously faced a number of challenges such as declining quality of educational programs, quality of research, authenticity of degrees granted, flexibility of the university programs, innovations created and efficient utilization of resources at their disposal. Despite the increasing number of students seeking higher education, these numbers have not translated to better performance in these Universities. Modern business environment calls for organizations, including private Universities to identify and exploit strategic capabilities for them to effectively compete and boost their performance. These universities need to harness their resources, and exploit their competences in order to gain competitive advantage. There is therefore a need for private universities to consider networking capability by creating, maintaining, and utilising relationships with relevant stakeholders in order to boost their performance. This study sought to establish the effect of networking capability on performance of private universities in Kenya. The study was anchored on the Resource Based View theory. It was founded on positivist research philosophy and adopted a cross-sectional descriptive survey research design. Primary data collected from faculty deans, registrars' administrations and finance, human resource managers and ICT managers was used in the study. Data analysis was carried out using descriptive statistics; means, frequencies and standard deviations and inferential statistics (correlation and regression analysis). The study established that private universities adopted networking capability only to a moderate extent (mean=3.39). There was a significant effect of relational trust $(\beta=0.194 ; \mathrm{P}=0.001)$, relational capability $(\beta=0.079 ; \mathrm{P}=0.000)$, relational strength $(\beta=0.103 ; \mathrm{P}=0.017)$, coordination within networks $(\beta=0.106 ; \mathrm{P}=0.010)$, and information sharing $(\beta=0.278 ; \mathrm{P}=0.000)$ on performance of private universities. Initiation of business relationships $(\beta=0.053 ; \mathrm{P}=0.412)$, and learning for success $(\beta=0.007 ; \mathrm{P}=0.926)$ had no significant effect on university performance. Overall, the study concluded that networking capability has a significant effect on performance of private universities in Kenya. Based on this conclusion, the study recommended that that private universities in Kenya should focus on ways of creating, maintaining, and maximizing avenues for information sharing, trust amongst stakeholders, inter-university relations, strengthen relations, and improve coordination within their networks. The study contributes to the body of knowledge by proposing a strategic capability model for private universities (and to a great extent public universities) for improving their performance by redirecting their focus to networking capability.
\end{abstract}

Keywords: Networking Capability, Organization Performance, Private Universities

\section{Introduction}

There has been a consistent increase in the number of private universities in Kenya over the past decade [1]. The emergence of these universities has led to increase in enrolment rate of students seeking for spaces in institutions of higher learning. Additionally, [2] that private universities have increased in the last two decades. This increase in the number of universities has increased competition among both private and public universities [3]. However, although the number of 
students seeking higher education in these universities increased initially, the numbers have declined in the recent past exposing the universities to new challenges [4].

Further, universities in Kenya and more specifically private universities have failed to produce graduates who meet industry demands. This has been attributed to factors such as inadequate financial resources, declining quality of educational programs, quality of research, authenticity of degrees granted, flexibility of the university programs, innovations created and efficient utilization of resources at their disposal [5]. There is therefore need to explore the applicability of strategic capabilities such as networking capability as a precedent to better performance in these universities. Organisations need to formulate effective business strategies if they are to survive in a competitive environment [6].

Strategic capabilities considers the strategies an enterprise has with regard to the firm's assets, competencies and resources used by the firm to exploit its resources to gain competitive advantage [7]. Networking capability of an organisations is its ability to come up, maintain, successfully handle, and make use of relationships with relevant stakeholders [8]. Networking capability has been defined as the successful initiation of relationships by an organisation with other organisations and ensuring that the firm gains from these relationships [9]. Further, it is defined as the ability of an organisation to manage and accrue benefits from external relationships [10].

The essence of networking capability is amplified by the fact that organisation networks are part of the other organisation abilities which make it extremely difficult to separate them [11]. Firms that network are able to eliminate constrains and competition arising from resources, innovation, competence and skills which results in better performance [12]. Further, networking allows organizations to get resources and improve performance. This is because networks are supportive, reduce risks, and enhance their performance [12]. Similarly, firm performance is affected by the network the organisation has and the relationship the organisation has with others at a personal level [13]. Consequently, strategic networking capabilities are paramount in the course of attaining competitive advantage and superior performance.

\section{Statement of the Problem}

Due to the growing pressures related to declining quality of educational programs, quality of research, authenticity of degrees granted, flexibility of the university programs, innovations created, and the utilization of resources, private universities in Kenya have been reporting poor performance [14]. Despite the increasing number of students seeking higher education, these numbers have not translated to better performance of the private Universities. The ranking of these universities in terms of academic research, regional and global reputation, as well as employability of graduates also show that private universities in Kenya rank poorly with
Strathmore University leading the pack of private universities at position four followed by Mount Kenya University and United States International University-Africa in position seven and eight respectively [15]. In Africa none of private universities in Kenya appeared in the best fifty in ranking.

Owing to poor performance, Commission for University Education in Kenya has in the last few years, recommended closure and sanction of four universities including Inoorero University, Landmark University, Barack Obama University, and Kenco University for awarding degrees to students without following laid-down procedures, enrolling unqualified students and offering courses not approved by the commission [15]. The commission recommended the revocation of the letter of interim authority awarded to Presbyterian University for lack of adequate resources to meet its obligations while at the same time Catholic University of East Africa (CUEA) and Kenya Methodist University (KeMU) were put on notice to change their operations in order to achieve the needed finances, failure to which they risked their charters being nullified. Clearly, it is evident that private universities in Kenya face challenges associated with their poor performance [15].

Previous scholars have tied networking capability to numerous variables. It is supported that social networking helps improve media houses performance [15]. It was also concluded that strategic business networking is a prerequisite for gaining competitive advantage and better performance [17]. Networking capability is positively correlated with business performance [11]. It is also alluded that networking capability improves firm performance [18-19].

While several studies have been conducted on the relationship between networking capability and performance, there are still gaps existing in literature. Most studies focused on the direct relationship existing between the variables while ignoring the causal effect and the magnitude of the effect. Other studies were conducted in other contexts other than private universities while others related networking capability to other variables such as competitive advantage and not performance. This study therefore establishes that there exist contextual, conceptual, and empirical gaps in literature which need to be filled. This study therefore sought to fill these gaps by investigating the effect of networking capability on performance of private universities in Kenya.

\section{Literature Review}

\subsection{Resource Based View}

The resource based theory provides that an organisation superior performance is possible due to the use of the resources the firm owns or controls [20]. The model further indicates that the way the organisation uses the resources affects its performance [21]. The theory emphasis on the resources characteristics and the capabilities acquired due to these characteristics leading to a sustainable performance [22]. Resources are a source of advantage such that a firm can dominate its rivals based on the way they build, position 
and safeguard the resources that are distinct and allow them to gain an advantage over their rivals [23].

It is worth to note that resources are made up of the capabilities and competencies of the firm [24]. According to the definition of resources in strategic management literature, they are the stock of things that belong to the organisation. Competencies are regarded as the organisations abilities that allow for differentiation or improved service delivery of quality by use of technological systems that are more responsive, which results to the organisation gaining a competitive advantage in the marketplace [25]. Resource Based View is essential in strategic management as it concentrates on an organisations resources as the key source of enhanced performance and a competitive advantage in the market [26].

Further, capabilities are made up of a firms' knowledge, ability, skills, and experiences that makes it possible for the firm to operate and use its resources to perform effectively [27]. The model allows the management to check if they have capabilities and resources that can enable the firm gain superiority and competitive advantage [28]. If an organisation is to achieve CA and enhance its performance then the resources under its ownership have to be rare, valuable, non-substitutable and inimitable [24]. These resources are either tangible or intangible. Tangible resources are physical in nature such as raw materials, facilities, and equipment while intangible resources are not physical and can include organisational values, brand, processes, and networks of the firm. Intangible resources are likely to result to a competitive advantage compared to the tangible ones making the model essential in supporting the firm's networking capability and performance [25].

The RBV theory has however been critiqued just as it has been supported. One of the critics is that it makes the reality in a firm seem too simple and also assumes there is a linear relationship between competitive advantage, firm resources, and the organisation performance [22]. Further, the model ignores environmental factors that affect the performance of the organisation. However, in reality the organisation resources might not have any relationship with its performance. However, this study still used this theory as relevant in anchoring networking capability and performance of Kenyan private universities.

\subsection{Empirical Literature}

In a longitudinal case study of manufacturing firms in New Zealand, the researcher sought to establish the role of business networks in the internationalization of manufacturing firms [29]. Further, a study seeking to determine the networking capability related factors that improved the performance of German, Chinese, and Turkish companies concluded that factors affecting performance varied across countries [18]. On the other hand, it was concluded that in cases of environmental uncertainties, network capability help improve the performance of architectural companies while managerial capability help in the real estate firm's performance [19].
In Kenya, it is shown that majority of the media houses have social media accounts such as Facebook, twitter and YouTube profiles and they carryout advertisements on their social network profiles [16]. On the other hand, in an evaluation of strategic business networking and competitive advantage in Kenyan large insurance firms it was observed that over $90 \%$ of large insurance companies in Kenya engage with more than five strategic business partners [17]. Further, international networks in innovation process has been postulated as a source of competitiveness in small and medium sized enterprises in Nairobi City County [30].

Based on the reviewed empirical literature it is evident that there is a gap in literature. Many of the studies conducted previously have considered only one strategic resource or have considered strategic capabilities as a construct in totality. The current study however has disintegrated strategic capabilities to focus on the effect of networking capability on performance of private universities in Kenya.

\subsection{Conceptual Framework}

Based on the reviewed literature the study developed the conceptual framework shown in figure 1. The conceptual framework outlines the relationship expected to persist between networking capability and performance of private universities in Kenya. It is anticipated that networking capability as measured through network characteristics, research facilities, and network resources directly affects performance of private universities in Kenya.

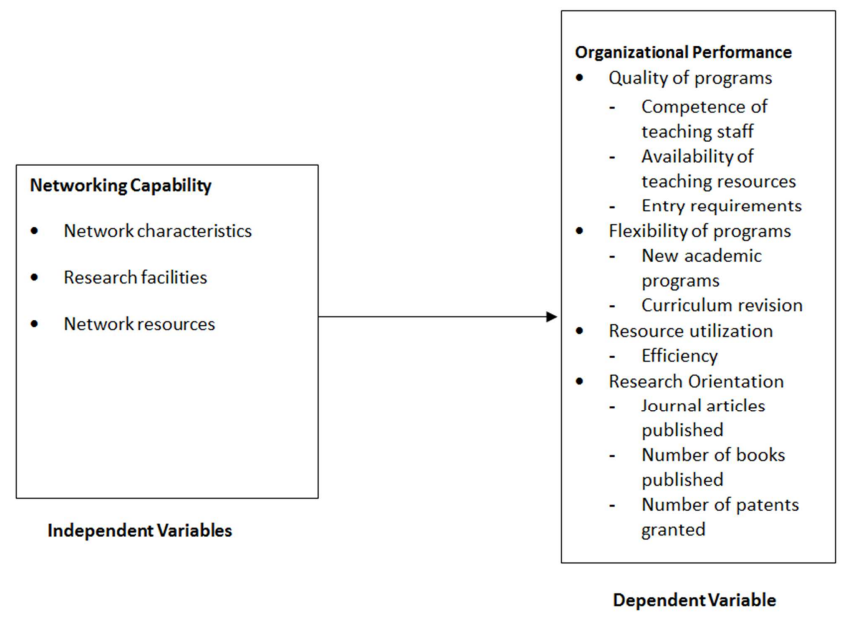

Source: Author (2019).

Figure 1. Conceptual Framework.

Arising from reviewed literature and resulting conceptual framework it is hypothesised that:

H0: Networking capability has no significant effect on performance of Private Universities in Kenya.

H1: Networking capability has a significant effect on performance of Private Universities in Kenya.

\section{Research Methodology}

The study used a positivist research philosophy which 
makes it easier to determine probable relationship existing between study constructs [31]. Furthermore, the philosophy explains relationships by noting causes that affects results giving a basis for generalisation and prediction. In addition, positivism research philosophy is suitable for any statistical inquiry that seeks to offer a rational explanation concerning the relationship between research variables [32]. The current research sought to use quantitative data to provide an explanation on the relationship between networking capabilities and performance of Private Universities in Kenya. The major assumption of the positivist philosophy is that firms are rational and they seek rational explanations and solutions to their rational challenges [31]. In addition, the study adopted a cross-sectional descriptive survey research design. This is because a descriptive survey is concerned with the process of data collection to help in the study hypothesis testing and answer the research questions [33]. This research design has been successfully used in past empirical studies [34-36].

The research targeted all 31 private universities in Kenya as at $31^{\text {st }}$ December 2016. Proportionate stratified sampling method was used to choose the 153 respondents who were the sample from all the private universities in Kenya representing $60 \%$ of the target population. The study used structured questionnaire to collect primary data. The validity of this questionnaire was confirmed through the use of opinion from experts in strategic management and extensive review of relevant body of literature. The reliability of the questionnaire was measured through Cronbach Alpha where a coefficient of greater than 0.7 was accepted as reliable. The results were as shown in Table 1.

Table 1. Reliability Coefficients.

\begin{tabular}{llll}
\hline Variable & Number of Items & Cronbach's Alpha Coefficient & Conclusion \\
\hline Network Capability & 22 & 0.888 & Reliable \\
Performance & 18 & 0.727 & Reliable \\
Overall & & 0.808 & Reliable \\
\hline
\end{tabular}

Source: Research Data (2019).

From the Results shown in table 1, it was observed that all constructs had their Cronbach's Alpha Coefficient greater or equal to 0.7 with the aggregate coefficient being 0.808 . It was thus concluded that the study constructs were reliable.

Primary data was collected from the respondents who included the faculty deans, registrar administration and finance, human resources managers and ICT managers. Descriptive statistics including means, frequencies and standard deviations were used for quantitative data analysis and presented inform of tables. In addition, inferential statistics was also carried out using correlation analysis and simple linear regression analysis to establish the extent and nature of the relationship between the variables of the study [37]. The adjusted coefficient of determination (R-squared $\left(R^{2}\right)$ was used to show the extent to which the changes in the performance of the organization is explained by changes in networking capability in Private Universities in Kenya.
Additionally, F-statistic was also tested at a confidence level of $95 \%$ to test the existence of a significant relationship between networking capability and performance of private universities in Kenya.

\section{Descriptive Results}

The study sought to determine the extent to which each indicator of networking capability and university performance was adopted in private universities in Kenya.

\subsection{Networking Capability}

This section presents mean scores, standard deviation, minimum, and maximum values for adoption of each study variables. Table 2 shows the mean and standard deviations for all the measurements of networking capability.

Table 2. Descriptive Statistics for Networking Capability.

\begin{tabular}{|c|c|c|c|c|c|}
\hline & $\mathbf{N}$ & Min. & Max. & Mean & Std. Dev. \\
\hline \multicolumn{6}{|l|}{ Learning for success } \\
\hline We produce the best students in the country & 127 & 2 & 5 & 3.67 & .827 \\
\hline We always try to increase the quality of our programmes & 127 & 2 & 5 & 4.23 & .936 \\
\hline Average & 127 & 2 & 5 & 3.95 & 0.88 \\
\hline \multicolumn{6}{|l|}{ Relational trust } \\
\hline we always cultivate trust amongst our staff & 127 & 1 & 5 & 3.94 & .970 \\
\hline Sharing of information among staff members & 127 & 1 & 5 & 3.64 & .957 \\
\hline Members interact with other stakeholders for information. & 127 & 1 & 5 & 3.46 & 1.194 \\
\hline Average & 127 & 1 & 5 & 3.68 & 1.04 \\
\hline \multicolumn{6}{|l|}{ Relational capability } \\
\hline Inter university interactions in open forums & 127 & 2 & 5 & 3.78 & .744 \\
\hline Business partnerships with other partner organizations & 127 & 1 & 5 & 3.51 & 1.046 \\
\hline We encourage and promote networking in order to maintain a strong relationship. & 127 & 1 & 5 & 3.24 & 1.035 \\
\hline Average & 127 & 1.333 & 5 & 3.51 & 0.94 \\
\hline \multicolumn{6}{|l|}{ Relational strength } \\
\hline We maintain strong bonds with our partners. & 127 & 1 & 5 & 3.61 & 1.085 \\
\hline We endeavour to create a good relational strength with our stakeholders & 127 & 1 & 5 & 3.19 & 1.037 \\
\hline
\end{tabular}




\begin{tabular}{|c|c|c|c|c|c|}
\hline & $\mathbf{N}$ & Min. & Max. & Mean & Std. Dev. \\
\hline We maintain good relational standings in our membership associations. & 127 & 1 & 5 & 2.82 & 1.065 \\
\hline Average & 127 & 1 & 5 & 3.21 & 1.06 \\
\hline \multicolumn{6}{|l|}{ Initiation of business relationships } \\
\hline We offer opportunities to partners within our networks & 127 & 1 & 5 & 3.08 & 1.245 \\
\hline We always generate new businesses from our existing networks. & 127 & 1 & 5 & 2.89 & 1.163 \\
\hline Our university partners with other stakeholders & 127 & 1 & 5 & 2.72 & 1.125 \\
\hline We always create new linkages to generate more business & 127 & 1 & 5 & 2.64 & 1.139 \\
\hline \multicolumn{6}{|l|}{ Coordination within networks } \\
\hline We coordinate with our stakeholders for a common understanding. & 127 & 1 & 5 & 3.38 & 1.031 \\
\hline Our university always try to bring order within our networks for cordial interactions. & 127 & 1 & 5 & 2.74 & .856 \\
\hline This university always provide guidelines rules and regulations to follow within the networks. & 127 & 1 & 5 & 3.20 & 1.084 \\
\hline $\begin{array}{l}\text { Networks created and managed by the university have a clear chain of command and } \\
\text { communication channels. }\end{array}$ & 127 & 1 & 5 & 3.40 & .962 \\
\hline Average & 127 & 1 & 5 & 3.180 & 0.983 \\
\hline The university provides platforms to enable information sharing & 127 & 1 & 5 & 4.17 & 1.024 \\
\hline The university has a policy on information sharing & 127 & 1 & 5 & 3.31 & 1.058 \\
\hline Average & 127 & 1 & 5 & 3.80 & 1.01 \\
\hline Average for Networking capability & 127.00 & 1.22 & 5.00 & 3.39 & 1.01 \\
\hline
\end{tabular}

Source: Research Data (2019).

The results in Table 2 shows that networking capability was utilised in Private universities to a moderate extent as shown by a mean of 3.39. However, the standard deviation of 1.01 indicated that the respondents varied in their opinions regarding the utilisation of networking capabilities among the private universities. Learning for success was to a large extent practised in private universities as a shown by a mean of 3.95. This view was held by a majority of the respondents as reflected by the lowest standard deviation of 0.88 . Initiation of business relationships had the lowest mean of 2.83 indicating that the respondents felt that initiation of business relationships in private universities was only emphasised to a moderate extent. There was however no consensus on this attribute among the respondents as shown high variations with a mean score of 1.168 thus suggesting that some universities indeed emphasised initiation of business relationships while others didn't.

These results allude that although some private universities in Kenya treasured cultivating and strengthening relational trust, most of them failed to appreciate the relevance of information sharing and coordinating within the available networks. There is thus need for these universities to entrench and embrace networking to fully realise the potential of the institutions and other stakeholders. To increase their networking capability in private universities there is also need emphasise on initiating of business relationships.

\subsection{University Performance}

This section presents mean scores, standard deviation, minimum, and maximum values for adoption of university performance as shown in Table 3.

Table 3. Descriptive Statistics for Performance.

\begin{tabular}{|c|c|c|c|c|c|}
\hline & $\mathbf{N}$ & Min. & Max. & Mean & Std. Dev. \\
\hline \multicolumn{6}{|l|}{ Customer Satisfaction } \\
\hline Competence teaching staff & 127 & 1 & 5 & 3.94 & 1.197 \\
\hline Average & 127 & 1 & 1 & 3.94 & 1.197 \\
\hline \multicolumn{6}{|l|}{ Availability of Teaching Resources } \\
\hline We have adequate number of lecturers & 127 & 2 & 5 & 3.76 & .879 \\
\hline We have enough computer laboratories for IT classes & 127 & 1 & 5 & 3.35 & 1.116 \\
\hline Our university has enough lecture halls to accommodate the growing number of students & 127 & 1 & 5 & 3.11 & 1.041 \\
\hline Average & 127 & 1.33 & 5.00 & 3.41 & 1.01 \\
\hline \multicolumn{6}{|l|}{ Entry Requirements } \\
\hline We follow the set standards by the commission for university education & 127 & 1 & 5 & 3.83 & .852 \\
\hline The university has provided a favourable entry requirement for the programmes offered & 127 & 1 & 5 & 3.52 & 1.126 \\
\hline Our university have developed a system where students can be enrolled without having to clear the fees at once & 127 & 1 & 5 & 3.24 & 1.118 \\
\hline Average & 127 & 1 & 5 & 3.53 & 1.031 \\
\hline \multicolumn{6}{|l|}{ Non-academic Programmes } \\
\hline The university has extensively adopted new academic programmes to boost quality of its education & 127 & 2 & 5 & 4.06 & .937 \\
\hline Our university is always the first to come up with new academic programs & 127 & 1 & 5 & 3.65 & 1.115 \\
\hline Average & 127 & 1.50 & 5.00 & 3.86 & 1.031 \\
\hline \multicolumn{6}{|l|}{ Curriculum Revision } \\
\hline Our school curriculum is always up to date & 127 & 2 & 5 & 3.99 & .947 \\
\hline We revise our curriculum basing on the guidelines set by the commission for university education & 127 & 1 & 5 & 3.91 & 1.218 \\
\hline Average & 127 & 1.5 & 5 & 3.95 & 1.083 \\
\hline
\end{tabular}




\begin{tabular}{|c|c|c|c|c|c|}
\hline & $\mathbf{N}$ & Min. & Max. & Mean & Std. Dev. \\
\hline \multicolumn{6}{|l|}{ Efficiency } \\
\hline We are able to conduct and run our activities efficiently & 127 & 1 & 5 & 3.51 & 1.053 \\
\hline Our university has not faced any challenge in terms of facilitation & 127 & 1 & 5 & 1.92 & 1.095 \\
\hline Average & 127 & 1 & 5 & 2.72 & 1.074 \\
\hline \multicolumn{6}{|l|}{ Journal Articles Published } \\
\hline our university has published several research articles over the years & 127 & 2 & 5 & 3.64 & .794 \\
\hline Our university offers support and guidelines on how students can publish their work & 127 & 1 & 5 & 3.51 & .825 \\
\hline We partner with journal to help our students publish their research work & 127 & 1 & 5 & 3.30 & 1.101 \\
\hline Average & 127 & 1.33 & 5.00 & 3.48 & 0.91 \\
\hline \multicolumn{6}{|l|}{ Number of Books Published } \\
\hline Our lecturers have been facilitated to publish books & 127 & 2 & 5 & 3.71 & .935 \\
\hline We support and guide students to publish books & 127 & 2 & 5 & 3.61 & .953 \\
\hline Average & 127 & 2 & 5 & 3.66 & 0.944 \\
\hline Average for Performance & 127 & 1.33 & 4.50 & 3.57 & 1.035 \\
\hline
\end{tabular}

Source: Research Data (2019).

Table 3 shows that the average mean score for performance was 3.57 which means that the respondents agreed that organisational performance had improved. At the same time the results showed that the respondents differed in their opinions on the extent to which of private universities in Kenya have achieved their set goals and objectives as shown by a high standard deviation of 1.035 . The results further showed that respondents believed that curriculum revision had improved in private Universities in Kenya as indicated by a mean score of 3.95 . However, there was a high variation in the observations as shown by an average standard deviation of 1.083. This means that private universities curriculum is always up to date and that the universities revised their curriculum based on the guidelines set by the commission for university education. Efficiency on the other hand remained unchanged as shown by a mean of 2.72 . However, it was noted that some of the respondents did not agree that efficiency remained constant in private universities in Kenya as shown by the high standard deviation of 1.074. The results indicate that the universities were in a position to conduct and run our activities efficiently but had challenges in terms of facilitation

\section{Inferential Analysis}

The objective of the study was to establish the effect of networking capability on performance of private Universities in Kenya. To achieve the objective, the study relied on correlation analysis and regression analysis.

\subsection{Correlation Analysis}

Correlation analysis was conducted to establish the direction and the strength of the association of variables in the study [37]. The results of the correlation analysis were as shown in Table 4.

Table 4. Correlations Analysis Results.

\begin{tabular}{|c|c|c|c|}
\hline & & University Performance & Networking capability \\
\hline University Performance & $\begin{array}{l}\text { Pearson Correlation } \\
\text { Sig. (2-tailed) }\end{array}$ & 1 & \\
\hline & $\mathrm{N}$ & 127 & \\
\hline Networking capability & $\begin{array}{l}\text { Pearson Correlation } \\
\text { Sig. (2-tailed) } \\
\text { N }\end{array}$ & $\begin{array}{l}.436^{* *} \\
.000 \\
127\end{array}$ & $\begin{array}{l}1 \\
127\end{array}$ \\
\hline
\end{tabular}

**. Correlation is significant at the 0.01 level (2-tailed).

*. Correlation is significant at the 0.05 level (2-tailed).

Source: Research Data (2019).

The results in Table 4 indicated that there exist a moderate positive correlation between organisational performance and networking capability $(\mathrm{r}=0.436 ; \mathrm{n}=127 ; \mathrm{p}<0.05)$. Generally, the results indicate that there was a positive correlation between organisational performances networking capability. These results concurred with the conclusions that business organisation achieve better results by engaging in networking to eliminate constrains and competition that has to do with its resources, innovation, competence and skills [7].

\subsection{Regression Analysis Results}

Networking capabilities was regressed on university performance. The output of this regression analysis are presented in Tables 5, 6 and 7.

Table 5. Model Summary for Network Capabilities.

\begin{tabular}{lllll}
\hline Model & R & R Square & Adjusted R Square & $\begin{array}{l}\text { Std. Error of } \\
\text { the Estimate }\end{array}$ \\
\hline 1 & $.562^{\mathrm{a}}$ & .316 & .276 & .35575 \\
\hline
\end{tabular}

a. Predictors: (Constant), Information sharing, Relational Trust, Relational capability, Relational strength, Coordination within networks, Learning for success, Initiation of business relationships.

The results from Table 5 shows that the coefficient $\mathrm{R}$ squared was 0.276 indicating that the model predicted $27.6 \%$ 
changes in the performance of private universities in Kenya. The results also imply that the remaining $72.4 \%$ of the performance was predicted by other factors other than those included in the model. Analysis of Variance (ANOVA) was conducted to establish the fitness of the model in predicting performance of private universities, the results were as shown in table 6 .

Table 6. ANOVA $A^{a}$ for Network Capabilities.

\begin{tabular}{llllll}
\hline Model & & Sum of Squares & Df & Mean Square & F \\
\hline \multirow{3}{*}{1} & Regression & 6.955 & 7 & .994 & 7.851 \\
& Residual & 15.061 & 119 & $.000^{\mathrm{b}}$ & \\
& Total & 22.016 & 126 & & \\
\hline
\end{tabular}

a. Dependent Variable: University Performance.

b. Predictors: (Cons tant), Information sharing, Relational Trust, Relational capability, Relational strength, Coordination within networks, Learning for success, Initiation of business relationships.

The results in Table 6 showed that the F-Statistic for the model was $(7,119=7.851)$ which was found to be greater than the F critical of 2.087. This indicates that the model was fit in predicting university performance. Similarly, the results shows the $\mathrm{P}$ value for the model to be 0.000 which is less than the significance level of 0.05 . The results above indicate that the model was significant in predicting university performance.

The study also conducted a student t-test to test the significance of study variables in predicting university performance. The results were as shown in Table 7.

Table 7. Regression Coefficients.

\begin{tabular}{|c|c|c|c|c|c|}
\hline \multirow{2}{*}{ Model } & \multicolumn{2}{|c|}{ Unstandardized Coefficients } & \multirow{2}{*}{$\begin{array}{l}\text { Standardized Coefficients } \\
\text { Beta }\end{array}$} & \multirow[t]{2}{*}{$\mathbf{T}$} & \multirow{2}{*}{ Sig. } \\
\hline & B & Std. Error & & & \\
\hline (Constant) & 3.305 & .326 & & 10.153 & .000 \\
\hline Relational Trust & .194 & .056 & .289 & 3.457 & .001 \\
\hline Relational capability & .079 & .021 & .217 & 3.762 & .000 \\
\hline Relational strength & .103 & .042 & .052 & 2.452 & .017 \\
\hline Initiation of business relationships & .053 & .064 & .121 & .823 & .412 \\
\hline Coordination within networks & .106 & .040 & .194 & 2.650 & .010 \\
\hline Information sharing & .278 & .075 & .480 & 3.716 & .000 \\
\hline
\end{tabular}

a. Dependent Variable: University Performance.

The results in Table 7 indicate that if all factors were held constant at zero, performance of private universities in Kenya would be 3.305 as shown by the constant. The results also show that holding all other factors constant and increasing relational trust by one unit, performance of private universities in Kenya would increase by 0.194 . In addition, the results revealed that holding all other factors constant and relational capability increased by one unit, private university performance in Kenya would increase by 0.079 . Similarly, if all factors were held constant, a unit increase in relational strength would result to an increase in university performance by 0.103 .

Furthermore, if initiation of business relationships was increased by one unit, performance of private universities in Kenya would increase by 0.053 . Holding all the factors constant, a unit increase in coordination within networks would result in an increase in performance of private universities in Kenya by 0.106 . At same the time if learning for success was increased by one unit while holding all other factors constant, performance of private universities would increase by 0.007 . Similarly, a unit increase in information sharing would result to an increase in university performance by 0.278 provided all other factors are held constant. In terms of magnitude, information sharing has the highest effect on university performance. The results also indicated that all the variables apart from initiation of business relationships and learning for success were significant in predicting performance since they had a $\mathrm{P}$ value less than 0.05 .

The results found on the effects of various aspects of networking capability were in line with the findings of the study asserting that capabilities of a firm allow it to daily operate, grow, adapt to changes and to achieve a competitive advantage in the industry [38]. Further, cooperation within networks which are directed towards innovation positively affects firm performance [8]. However, initiation of business relationships and learning for success had $\mathrm{P}$ values greater than 0.05 hence were found to be insignificant in predicting university performance.

\section{Conclusion}

From the results, the study concluded that networking capability has a significant positive effect on performance of private universities in Kenya. The study found that networking capability was utilised in Private universities to a moderate extent. The study concluded that Information sharing was significant in influencing performance of private universities and was the main driving factor of performance. The study also concluded that relational trust, relational capability, relational strength and coordination within 
networks were all significant in influencing performance of private universities in Kenya. On the other hand, the study concluded that, initiation of business relationship and learning for success had no significant effect on performance of private universities in Kenya.

\section{Recommendations}

Based on the conclusions of the study, the study recommends that private universities in Kenya should focus on ways of maximising the utilisation of relational trust by cultivating trust amongst staff, relational capability by encouraging inter-university interactions in open forums, relational strength, initiation of business relationships, coordination within networks, and encouraging information sharing amongst their networks in order to boost performance. In addition, the University registrars should create strategic networks and partnerships that are unique and inimitable by other universities to enable them acquire innovations, resources, skills and competencies, thus improving performance. The findings of this study were limited only to private universities in Kenya and may not be generalised to other institutions of learning or other organisations. Other studies should therefore be conducted in public universities in Kenya and also in all the institutions of higher learning to identify if similar conclusions will be reached.

\section{References}

[1] Kagai, F. K. (2014). The impact of business alliances as a competitive advantage on a companys brand image and customer satisfaction: A case study of JKUAT. (Doctoral dissertation), University of Nairobi, Kenya.

[2] Cloete, N., Bunting, I., \& Maassen, P. (2015). Research universities in Africa: An empirical overview of eight flagship universities. Knowledge production and contradictory functions in African higher education, 1, 18.

[3] Gakenia. N. J. (2014). Effects of organizational resources, competitive advantage on firm's performance of mobile phone industry in Kenya. (Doctoral dissertation), Kenyatta University, Kenya.

[4] Njihia, M., Mwaniki, E., Ireri, A., \& Chege, F. (2020). Obstacles to successful uptake of open distance and e-learning (Odel) programmes: a case of Kenyatta University, Kenya. African multidisciplinary journal of research, 5 (12), 62-73.

[5] Abong'o, E. B. (2007). Responses adopted by private Universities in Kenya to cope with the changing higher Education Environment. (Unpublished MBA Project), University of Nairobi, Kenya.

[6] Hatch, N. W., \& Howland, C. (2015). When Does Competitive Advantage Improve Customer Welfare?. In Academy of Management Proceedings (Vol. 2015, No. 1, p. 18091). Briarcliff Manor, NY 10510: Academy of Management.

[7] Vesalainen, J., \& Hakala, H. (2014). Strategic capability architecture: The role of network capability. Industrial Marketing Management, 43 (6), 938-950.
[8] Cantn er, U., Conti, E., \& Meder, A. (2010). Networks and innovation: the role of social assets in explaining firms' innovative capacity. European Planning Studies, 18 (12), 1937-1956.

[9] Karami, M., \& Tang, J. (2019). Entrepreneurial orientation and SME international performance: The mediating role of networking capability and experiential learning. International Small Business Journal, 37 (2), 105-124.

[10] Balboni, B., Kocollari, U., \& Pais, I. (2014). How can social enterprises develop successful crowdfunding campaigns? An empirical analysis on Italian context (April 28, 2014).

[11] Zacca, R., Dayan, M., \& Ahrens, T. (2015). Impact of network capability on small business performance. Management Decision, 53 (1), 2-23.

[12] Parida, V., Pesämaa, O., Wincent, J., \& Westerberg, M. (2017). Network capability, innovativeness, and performance: a multidimensional extension for entrepreneurship. Entrepreneurship \& Regional Development, 29 (1-2), 94-115.

[13] Chimucheka, T. (2013). Overview and performance of the SMMEs sector in South Africa. Mediterranean Journal of Social Sciences, 4 (14), 783-783.

[14] Mathooko, F. M., \& Ogutu, M. (2014). Coping strategies adopted by public universities in Kenya in response to environmental changes. Journal of Management and Strategy, $5(1), 93$.

[15] Commission for University Education. (2016). A quarterly publication (January - May 2016). CUE. Retrieved from http://www.cue.or.ke/index.php/downloads/category/15newsletters.

[16] Nyaga, M. (2010). Business benefits of social networking in gaining leverage among media houses in Kenya (Doctoral dissertation), University of Nairobi, Kenya.

[17] Olalo, E. A. (2013). Strategic business networking and Competitive Advantage in Large Insurance firms in Kenya (Doctoral dissertation).

[18] Papastamatelou, J., Busch, R., Ötken, B., Okan, E. Y., \& Gassemi, K. (2016). Effects of Network Capability on Firm Performance across Cultures. International Journal of Management and Economics, 49 (1), 79-105.

[19] Srećković, M. (2018). The performance effect of network and managerial capability of entrepreneurial firms. Small Business Economics, 50 (4), 807-824.

[20] Penrose, E. T. (1959). The Growth of the Firm. Wiley: NewYork.

[21] Wernerfelt, B. (1984). A Resource-based View of the Firm. Strategic Management Journal, Vol. 5 (2), pp. 171-180.

[22] Kraaijenbrink, J., Spender, J. C., \& Groen, A. J. (2010). The resource-based view: A review and assessment of its critiques. Journal of management, 36 (1), 349-372.

[23] Molloy, J. C., Chadwick, C., Ployhart, R. E., \& Golden, S. J. (2011). Making intangibles "tangible" in tests of resourcebased theory: A multidisciplinary construct validation approach. Journal of Management, 37 (5), 1496-1518.

[24] Barney, J. B. \& Hesterly, W. S (2010). Strategic management and competitive advantage concept. Upper saddle River, N. J: Pearson Prentice Hall. 
[25] Arend, R. J. \& Levesque, M. (2010). Is the resource-based view a practical organizational theory? Organization Science, Vol. 21 No. 4, pp. 913-30.

[26] McKelvie, A. \& Davidsson, P. (2009). From resource base to dynamic capability: an investigation of new firms. British Journal of Management 20 (S1), S63-S80.

[27] Andersén, J. (2011). Strategic resources and firm performance. Management Decision, 49 (1), 87-98.

[28] Lockett, A., Thompson, S. \& Morgenstern, U. (2009). The development of the resource-based view of the firm: a critical appraisal, International Journal of Management Reviews, Vol. 11 No. 1, pp. 9-28.

[29] Chetty, S., \& Holm, D. B. (2000). The role of business networks in the internationalization of manufacturing firms: A longitudinal case study. Journal of business research, 69 (6), 205-222.

[30] Simaiya, S. C. (2016). International Networks in Innovation Process as a Source of Competitiveness in Small and Medium Sized Enterprises in Nairobi City County Central Business District (Doctoral dissertation), University of Nairobi, Kenya.

[31] Creswell, J. W. (2009). Research design: Qualitative, quantitative, and mixed methods research. Thousand Oaks, CA: Sage Publications, Inc. and mathematics anxiety in mathematics problem-solving efficiency. Learning and Individual Differences, 20 (3), 276-283.
[32] Kinyua, G. M. (2015). Relationship between Knowledge Management and Performance of Commercial Banks in Kenya. Doctoral Dissertation; Kenyatta University, Nairobi, Kenya.

[33] Marshall, C., \& Rossman, G. B. (2014). Designing qualitative research. Sage publications.

[34] Gatuyu, C. M. \& Kinyua, G. M. (2020). Role of Knowledge Acquisition on Firm Performance in the Context of Small and Medium Enterprises in Meru County, Kenya. Journal of World Economic Research, 9 (1): 27-32.

[35] Muthoni, D. M. \& Kinyua, G. M. (2020). Corporate Reputation and Firm Performance: An Empirical Analysis of Motor Vehicle Assemblers in Nairobi City County, Kenya. Journal of Business and Economic Development, 5 (2): 73-81.

[36] Ontita, J. \& Kinyua, G. M. (2020). Role of Stakeholder Management on Firm Performance: An Empirical Analysis of Commercial Banks in Nairobi City County, Kenya. Journal of Business and Economic Development, 5 (1): 26-35.

[37] Jobson, J. (2012). Applied multivariate data analysis: volume II: Categorical and Multivariate Methods. Springer Science \& Business Media.

[38] Kim, N., Shin, S., \& Min, S. (2016). Strategic marketing capability: Mobilizing technological resources for new product advantage. Journal of Business Research, 69 (12), 5644-5652. 